\title{
Pengaruh Inteligensi Linguistik terhadap Hasil Belajar Bahasa Arab Siswa Kelas XI MAN 1 Kota Cirebon
}

\author{
Titin Siti Patimah \\ Institut Agama Islam Negeri (IAIN) Syekh Nurjati Cirebon \\ Email: sitifatimaht43@gmail.com \\ Wawan Arwani \\ Institut Agama Islam Negeri (IAIN) Syekh Nurjati Cirebon \\ Email: wawanarwani@gmail.com \\ Masri'ah \\ Institut Agama Islam Negeri (IAIN) Syekh Nurjati Cirebon \\ Email: masriah59@gmail.com
}

\begin{abstract}
Abstrak
Penelitian ini bertujuan untuk mengetahui seberapa besar pengaruh antara Inteligensi linguistic terhadap hasil belajar siswa MAN 1 Kota Cuirebon. Dasar pemikiran dari penelitian ini adalah keputusan Menteri Pendidikan Nasional Nomor 027/U/2002 yang menyatakan bahwa akreditasi sekolah bertujuan untuk menentukan tingkat pencapaina sekolah dalam pelayanan pendidikan. Hasil akreditasi tersebut dinyatakan dalam akreditasi sekolah yang terdiri dari akreditasi A (sangat baik), B (baik), dan C (cukup). Adapun akreditasi untuk MAN 1 Kota Cirebon yaitu A yang berarti sangat baik. Tetapi akreditasi tersebut berbanding terbalik dengan kualitas hasil belajar siswanya, terutama hasil belajar siswa kelas XI MAN 1 Kota Cirebon. Oleh karena itu, peneliti tertarik untuk meneliti faktor internal yang berpengaruh terhadap hasil belajar siswa yaitu inteligensi linguistik. Penelitian ini menggunakan pendekatan kuantitatif dengan metode ex post facto. Medote pengumpulan data yang digunakan dalam penelitian ini adalah dengan cara penyebaran angket, wawancara dan dokumen , sedangkangkan analisis data dalam penelitian ini adalah dengan menggunakan penghitungan,uji normalitas, uji korelasi,uji regresi dan uji hipotesis. Hasil penelitian menunjukkan bahwa: (1) inteligensi linguistik siswa kelas XI MAN Kota Cirebon dengan persentase 69\% tergolong tinggi; (2) hasil belajar siswa dengan mean 61,43 tergolong sedang; (3) tidak ada pengaruh yang signifikan antara inteligensi linguistik dengan hasil belajar, dan pengaruhnya hanya sebesar 0,5\% ditunjukkan dengan nilai sig > 0,05 yaitu 0,687 >0,05, korelasi dalam penelitian ini tergolong sangat rendah. Ada 99,5\% faktor lain yang berpengaruh diantaranya bakat, motivasi, metode pembelajaran, guru, dan sebagainya.
\end{abstract}

Kata Kunci: Inteligensi Linguistik, Hasil Belajar, MAN 1 Kota Cirebon 


\section{Abstract}

This study aimed to determine how much influence between linguistic intelligence on learning outcomes of students of MAN 1 in Cirebon city. The rationale of this reserch is the decision of the Minister of National Education number 027/U/2002 wich states that school accreditation aims to determine the level of school achievement in education service. The results of the accreditation are stated in the school accreditation wich consists of accreditation A (very good), B (good), and C (sufficient). The accreditation of MAN 1 Kota Cirebon is A, wich means very good. But the accreditation inversely proportional to the quality of student learning outcomes, especially the learning outcomes of class XI MAN 1 Cirebon city. Therefore, the researcher interested in examining internal factors that influence students' learning outcome that is linguistic intelligence. This research used quantitative approach with ex-post facto method. The techniques of collecting data used questionnaire distribution, interview and documentation. The researcer analyzed the data used calculations, normality test, regression test and hypothesis tests. The results showed that: (1) linguistic intelligence of XI MAN grade students in Cirebon city with a percentage of $69 \%$ classified as high; (2) Students learning outcomes with a mean of 61,43 are classified as moderate; (3) There is no significant effect between linguistic intelligence and learning outcomes, and the effect only $0,5 \%$ indicated by a sig value $>0,05$ which is 0,687 $>0,05$, the correlation in this study is classified as very low. There are $99,5 \%$ of other influential factors including talent, motivation, learning methods, professional teachers, and so on.

Keywords: Linguistic Inteligence, Learning Result, MAN 1 Cirebon City

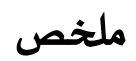

هذه الرسالة تبحث عن تأثير الذكاء اللغوي على تحصيل تعلم اللغة العربية لطلاب الفصل ملحصل

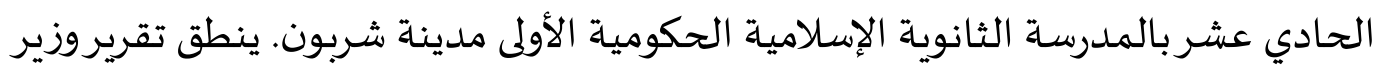

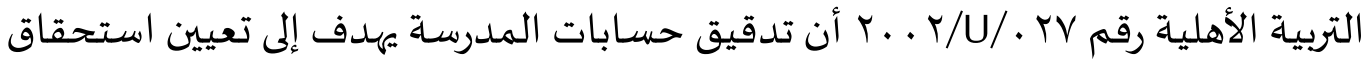
واجراء المدرسة في خدمة التربية. يؤكد تحصيل تدقيق حسابات المدرسة في منصب

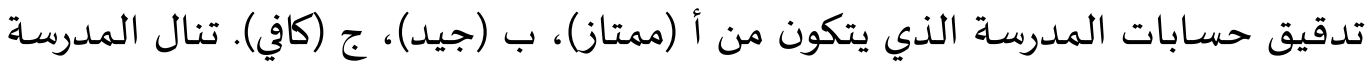

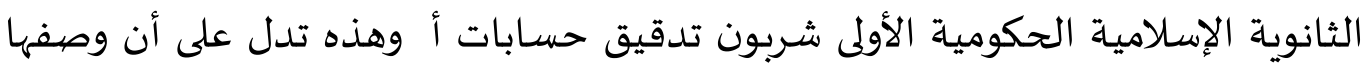

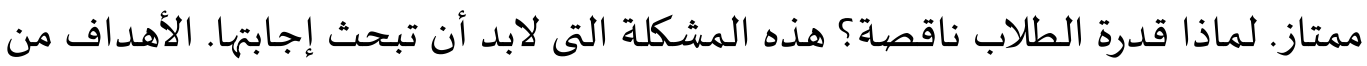
هذا البحث هي لمعرفة الذكاء اللغوي لطلاب الفصل الحادي عشر بالمدرسة الثانوية

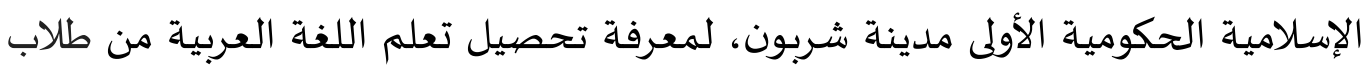

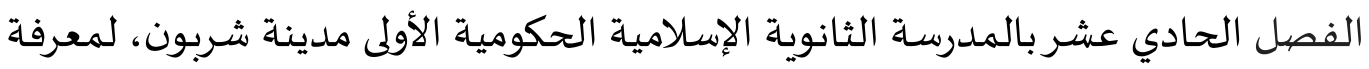


تأثير الذكاء اللغوي على تحصيل تعلم اللغة العربية لطلاب الفصل الحادي عشر بالمدرسة

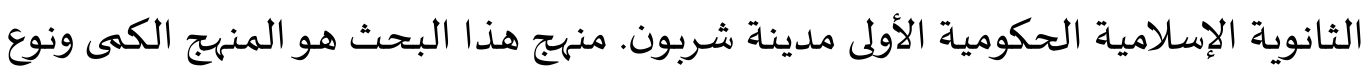

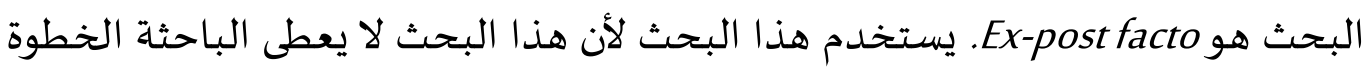

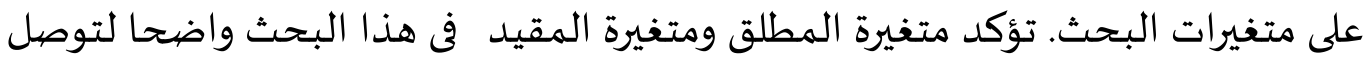

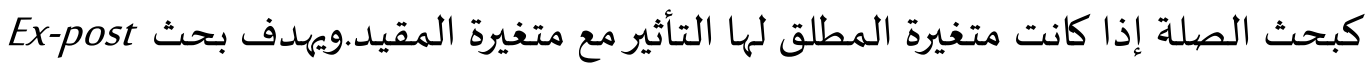

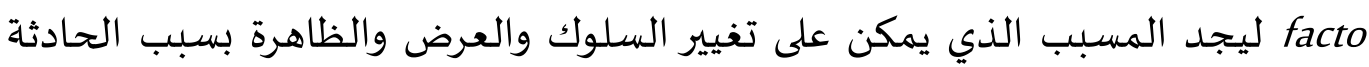

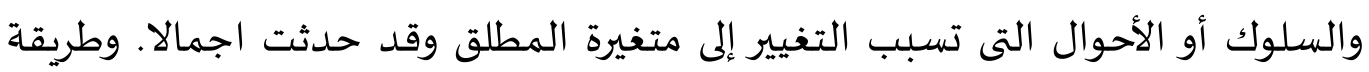

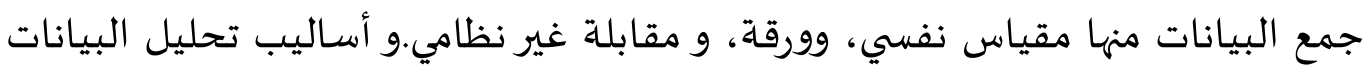

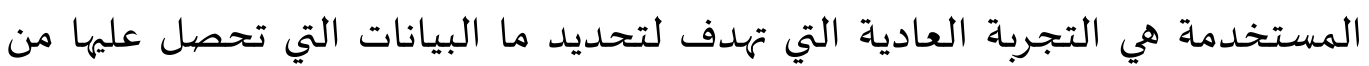
الرمزة التي تسهم طبيعي أولا وتحليل انحدار اعتدال البسيط وهو مقياس تدبير البيانات

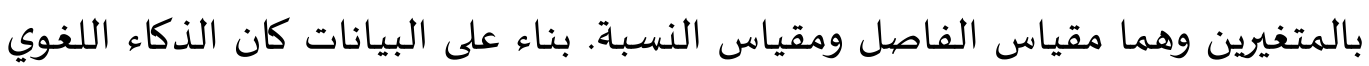

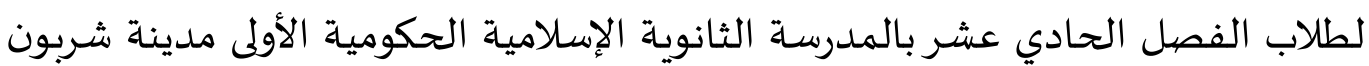
فى درجة عالية بنسبة مئوية 79\%. كان تحصيل تعلم اللغة العبية لطلاب الفصل الحادي

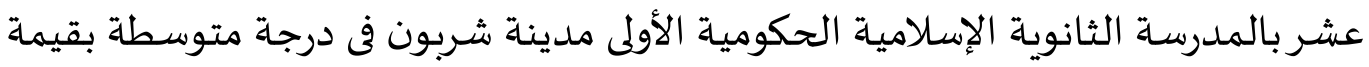

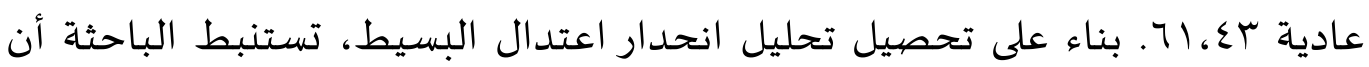

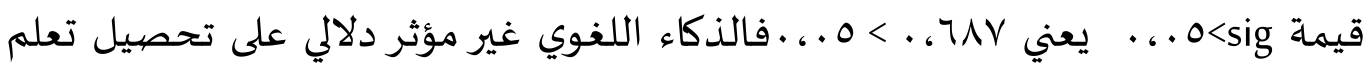

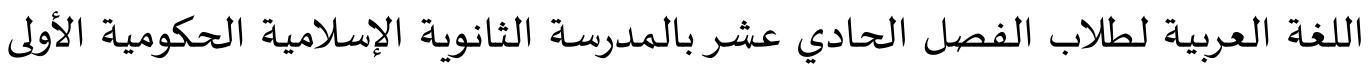

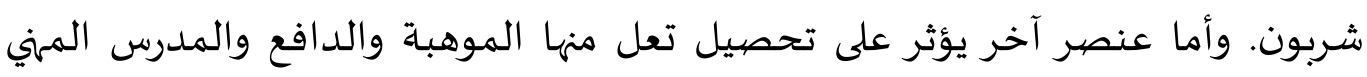
وطريقة التعليم.

\section{الكلمات الرئيسية: الذكاء اللغوي، تحصيل التعلم اللغة العربية، المدرسة العالية} الحكومية جيربون

\section{Pendahuluan}

Belajar pada hakikatnya merupakan hasil dari proses interaksi antara individu dengan lingkungan sekitarnya. Dalam melakukan proses ini, siswa menggunakan seluruh kemampuan dasar yang dimilikinya sebagai dasar untuk melakukan berbagai kegiatan agar memperoleh hasil belajar. ${ }^{1}$ Adapun tugas guru adalah membantu peserta didik memperoleh

${ }^{1}$ Warsono \& Hariyanti, Pembelajaran Aktif Teori dan Asesmen. (Bandung: PT. Remaja Rosdakarya, 2016). Hal. 7

El-Ibtikar Vol 9 No 2 Desember 2020 
informasi, ide, keterampilan, nilai cara berpikir, dan sarana untuk mengekspresikan dirinya. ${ }^{2}$

Pembelajaran substansinya adalah kegiatan mengajar yang dilakukan secara maksimal oleh seorang guru agar anak didik yang diajari materi tertentu melakukan kegiatan belajar dengan baik, sehingga dapat mencapai tujuan pembelajaran yang diinginkan. Dalam kegiatan pembelajaran terdapat pembelajaran bahasa asing dalam hal ini bahasa Arab yang bertujuan mengembangkan kemampuan siswa dalam menggunakan bahasa baik itu secara lisan maupun tertulis. Kemampuan menggunakan bahasa dalam dunia pengajaran bahasa disebut keterampilan bahasa (maharat al-lughah). Ketrampilan tersebut ada empat, yaitu keterampilan menyimak (maharat al-istima'), keterampilan berbicara (maharat al-kalam), keterampilan membaca (maharat al -qiraah), dan keterampilan menulis (maharat al -kitabah). ${ }^{3}$

Kemampuan berbahasa sangat diperlukan untuk bermasyarakat, baik dalam bentuk berbicara, membaca dan menulis. Berbicara, memungkinkan seseorang untuk memberi nama obyek yang nyata dan berbicara tentang obyek yang tidak terlihat. Membaca, membuat seseorang mengenal obyek, tempat, proses dan konsep yang tidak langsung dialami. Sedangkan menulis dapat membuat komunikasi dengan seseorang tanpa harus saling bertemu. ${ }^{4}$

Dalam proses pembelajaran terutama pembelajaran bahasa Arab, setiap peserta didik memiliki taraf inteligensi masing-masing yang harus dikembangkan. Salah satu inteligensi yang dimiliki oleh peserta didik adalah inteligensi linguistik. Inteligensi linguistik adalah kecerdasan dalam mengolah kata dan merupakan kecerdasan paling universal diantara ketujuh kecerdasan dalam teori kecerdasan ganda. Inteligensi linguistik adalah kecerdasan dalam mengolah kata atau kemampuan menggunakan kata secara efektif baik secara lisan maupun tertulis. ${ }^{5}$ Orang yang cerdas

${ }^{2}$ Hamzah B. Uno \& Masri Kuadrat, Mengelola Kecerdasan dalam Pembelajaran Sebuah Konsep Pembelajaran Berbasis Kecerdasan. (Jakarta: PT. Bumi Aksara, 2009). Hal. 4

${ }_{3}$ Acep Hermawan, Metode Pembelajaran Bahasa Arab. (Bandung: PT. Remaja Rosdakarya, 2011). Hal. 13

${ }^{4}$ Farhatin Masrurah, "Kecerdasan Verbal-Linguistik Anak Melalui Pendekatan Beyond Centers and Circle Time (BCCT)". vol 6 no. 2, ( Desember 2014). Hal. 1-30.

${ }^{5}$ Sudarwan Danim, Perkembangan Peserta Didik . (Bandung: Alfabeta, 2011). Hal. 123 
dalam bidang ini dapat berargumentasi, meyakinkan orang, menghibur atau mengajar dengan efektif lewat kata-kata yang diucapkan.

Oleh karena itu, inteligensi memegang peranan penting dalam mencapai keberhasila belajar siswa. Kemampuan belajar peserta didik, serta kemampuan guru mengetahui dan memanfaatkan inteligensi linguistik peserta didik akan tumbuh dalam mencapai tujuan pembelajaran. Sehingga tujuan pembelajaran yang diinginkan akan tercapai sesuai dengan indikator pencapaiannya.

Kecerdasan yang dimiliki peserta didik dalam hal ini yang menjadi salah satu faktor yang memengaruhi hasil belajar peserta didik. Menurut Bloom, Hasil belajar peserta didik hakikatnya adalah perubahan tingkah laku sebagai hasil belajar yang lebih luas mencakup bidang kognitif, afektif dan psikomotorik. Bidang kognitif terdiri dari tingkat pengetahuan siswa, bidang afektif tentang sikap dan perilaku siswa, dan bidang psikomotor yaitu tentang keterampilan siswa. untuk mengetahui hasil belajar peserta didik maka digunakan alat ukur berupa tes hasil belajar. ${ }^{6}$

Berdasarkan hasil wawancara bersama guru mata pelajaran Bahasa Arab kelas XI MAN 1 Kota Cirebon dan berdasarkan data hasil belajar siswa kelas XI MAN 1 Kota Cirebon, terdapat beberapa permasalahan dalam mata pelajaran bahasa Arab, di antaranya adalah hasil belajar peserta didik masih rendah. Oleh karena itu banyak peserta didik yang memiliki nilai di bawah KKM (Kriteria Ketuntasan Minimum). Padahal, sekolah ini memiliki akreditasi A yang seharusnya kualitas siswanya juga sesuai dengan akreditasi sekolahnya, akan tetapi kenyataan menunjukkan sebaliknya.

Keputusan Menteri Pendidikan Nasional nomor 027/U/2002 telah menetapkan bahwa akreditasi sekolah bertujuan untuk menentukan sejauh mana pencapaian sekolah dalam hal pelayanan Pendidikan. Akreditasi sekolah terdiri dari akreditasi A (sangat baik), B (baik), dan C (cukup baik). MAN 1 Kota Cirebon meraih akreditasi A, hal ini menunjukkan bahwa kualitas sekolah tersebut sudah sangat baik. Akan tetapi kenapa kemampuan siswa dalam mata pelajaran Bahasa Arab kurang?

${ }^{6}$ Agus Suprijono, Cooperative Learning Teori dan aplikasi PAIKEM. (Yogyakarta: Pustaka Pelajar, 2016). Hal. 6 
Berdasarkan uraian di atas, maka peneliti termotivasi untuk melakukan penelitian yang berjudul: "Pengaruh Inteligensi Linguistik terhadap Hasil Belajar Bahasa Arab Peserta Didik Kelas XI MAN 1 Kota Cirebon".

\section{Metode Penelitian}

Penelitian dengan judul "Pengaruh Inteligensi Linguistik terhadap Hasil Belajar Bahasa Arab Siswa Kelas XI MAN 1 Kota Cirebon" merupakan penelitian dengan pendekatan kuantitatif dengan metode Eks Post Facto. Paradigma dalam penelitian model eksperimen ini dapat digambarkan sebagai berikut:

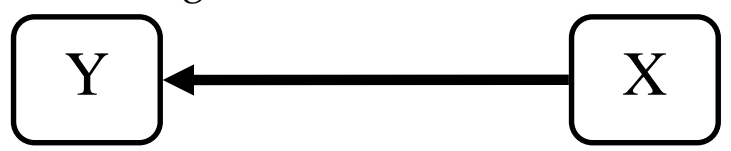

$X$ : Variabel Independen (Inteligensi Linguistik)

Y: Variabel Dependen (Hasil Belajar)

Populasi adalah suatu wilayah generalisasi yang tersusun atas subyek maupun obyek yang mempunyai kualitas dan ciri-ciri tertentu yang dipatenkan peneliti untuk dipahami dan dipelajari serta dibentuk suatu kesimpulan. ${ }^{7}$ Popuasi yang dipilih dalam penelitian ini yaitu seluaruh siswa kelas XI MAN 1 Kota Cirebon Tahun Ajaran 2019/2020 dengan jumlah keseluruhan 272 siswa, adapun rincian populasi sebagai berikut:

\begin{tabular}{|c|c|c|}
\hline No & Kelas & Jumlah \\
\hline 1 & XI IPA & 164 \\
\hline 2 & XI IPS & 108 \\
\hline
\end{tabular}

Sampel adalah wakil ataupun sebagian kecil populasi yang akan diteliti. Jika populasi berjumlah kurang dari 100, maka dianjurkan untuk mengambil seluruh populasi untuk dijadikan sampel, akan tetapi jika populasi berjumlah lebih dari 100, maka sampel yang diambil antara 10$15 \%$ dari populasi. ${ }^{8}$ Sampel yang diambil dalam penelitian ini yaitu siswa kelas XI IPA 4 MAN 1 Kota Cirebon, karena populasi lebih dari 100 maka

7Sugiyono, Metode Penelitian Kuantitatif, Kualitatif, dan RED. (Bandung: Alfabeta, 2012). Hal. 117.

${ }^{8}$ Suharsimi Arikunto, Prosedur Penelitian Suatu Pendekatan Praktek. (Jakarta: Rineka Cipta, 2006). Hal. 109. 
sebagian dari populasi dijadikan sample, teknik pemilihan sampel yang digunakan adalah purposive sample.

Metode pengumpulan data yang digunakan dalam penelitian ini yaitu dengan angket, wawancara dan dokumen. Lembar angket yang digunakan berisi beberapa indikator inteligensi linguistik dengan skala nilai 4: Sangat baik, 3: baik, 2: sedang,dan 1: kurang baik. Adapun angket yang didistribusikan kepada siswa adalah angket terkait inteligensi linguistik siswa yang berjumlah 20 soal yang didistribusikan kepada 32 siswa kelas XI MAN 1 Kota Cirebon. Sedangkan untuk megetahui hasil belajat siswa dilihat dari penilaian akhir semester 2. Wawancara yang dilakukan peneliti merupakan wawancara tidak terstruktur yang bersifat untuk memperkuat data dari angket.

Data nilai hasil belajar siswa didapat dari guru mata pelajaran Bahasa Arab kelas XI, setelah itu dilakukan wawancara terhadap guru pengampu mata pelajaran bahasa arab dan kepada beberapa siswa kelas XI MAN 1 Kota Cirebon.

Sumber data yang digunakan dalam penelitian ini yaitu guru pengampu mata pelajaran bahasa arab untuk mengetahui proses pembelajaran bahasa arab dikelas XI MAN 1 Kota Cirebon, baik dari metode, media maupun teknik pembelajaran yang digunakan guru selama proses kegiatan belajar mengajar. Sumber data yang kedua yaitu siswa kelas XI MAN 1 Kota Cirebon, untuk mengetahui kebiasaan belajar mereka dalam pembelajaran bahasa arab maupun sumber belajar yang mereka gunakan.

Teknik analisis data yang digunakan dalam penelitian ini dilakukan setelah semua data terkumpul dari instrumen yang sudah disiapkan untuk selanjutnya dianalisis untuk kemudian diperoleh hasil sesuai yang dibutuhkan dalam penelitian ini. Adapun teknik analisis data yang digunakan dalam penelitian ini sebagai berikut:

Uji validitas adalah suatu ukuran yang menunjukkan tingkat kevalidan dan kesahihan suatu instrumen. Suatu instrumen dikatakan valid apabila dapat mengungkap data dari variabel yang diteliti secaratepat. Validitas dalam penelitian ini diukur menggunakan program pengolahan data pada Microsoft Excel. Kriteria item yang valid yaitu dengan melihat hasil probabilitas. Jika nilai thitung>ttabel maka item dinyatakan valid. Jika thitung $<$ ttabel maka item dinyatakan tidak valid. 
Uji realibitas menunjuk pada satu pengertian bahwa sesuatu instrument sedang dapat dipercaya untuk digunakan sebagai alat pengumpul data karena instrumen sudah baik. ${ }^{9}$ Item yang valid akan dilakukan perhitungan reliabilitas dengan menggunakan rumus Cronbach's Alpha dengan tujuan mencari koefisien relibilitasnya. Reliabilitas dari skala ini diketahui dengan menggunakan program SPSS 16.0. Uji reliabilitas dengan tenik Cronbach's Alpha yaitu dengan cara menentukan nilai varian tiap butir pertanyaan, menentukan nilai varian total dan menentukan reliabilitas instrumen.

$$
\mathbf{r}_{11}=\left(\frac{\mathrm{k}}{(\mathrm{k}-1)}\right)\left(1-\frac{\sum \sigma_{\mathrm{b}}^{2}}{\sigma_{\mathrm{t}}^{2}}\right)
$$

Kriteria uji reliabilitas dengan rumus Cronbach's Alpha menggunakan batasan 0,6 . Suatu instrumen dikatakan reliabel jika nilainya sama dengan atau lebih daro 0,6, akan tetapi jika nilai instrumen tersebut kurang dari 0,6 maka bisa dikatakan instrumen tersebut tidak reliabel.

Uji normalitas berguna untuk mengetahui setiap sampel yang akan digunakan berasal dari populasi yang terdistrubusi normal atau tidak. Uji normalitas data pada penelitian ini dilakukan denganmenggunakan program pengolahan data SPSS versi 16.0 melalui uji normalitas Kolmogorov-Smirnov dengan kriteria jika signifikansi $>0,05$ maka data berdistribusi normal, dan jika signifikansi $<0,05$ maka data tidak berdistribusi normal.

Uji hipotesis digunakan untuk mengetahui ada tidaknya pengaruh antara variabel x (kebiasaan belajar siswa) dan variabel y (prestasi bahasa Arab). Uji hipotesis yang digunakan dalam penelitian ini menggunakan uji regresi sederhana dengan rumus.

$$
\mathrm{a}=\frac{\sum Y-b \sum X}{n}
$$

$n$

Kriteria uji hipotesis menggunakan uji regresi sederhana yaitu apabila diperoleh hasil thitung>ttabel dengan signifikasi < 0,05 maka Ha ditolak dan $\mathrm{H} 0$ diterima yang mana hal tersebut menunjukan bahwa adanya pengaruh antara variabel $x$ (inteligensi linguistik) dan variabel $y$ (hasil belajar bahasa Arab). Akan tetapi jika diperoleh hasil thitung<ttabel

${ }_{9}^{9}$ Tuti Hayati, Evaluasi Pembelajaran. (Bandung: CV Insan Mandiri, 2013). Hal. 121 
dengan signifikasi < 0,05 maka Ha diterima dan H0 ditolak yang mana hal tersebut menunjukan bahwa tidak adanya pengaruh antara variabel $\mathrm{x}$ (inteligensi linguistik) dan variabel y (hasil belajar bahasa Arab).

\section{Inteligensi Linguistik}

Menurut Martini Jamaris, inteligensi adalah interaksi aktif antara kemampuan yang dibawa sejak lahir dengan pengalaman yang diperoleh dari lingkungan yang menghasilkan kemampuan individu untuk memperoleh, mengingat dan menggunakan pengetahuan, mengerti makna dari konsep konkret dan konsep abstrak, memahami hubunganhubungan yang ada diantara objek, peristiwa, ide. Dan kemampuan dalam menerapkan semua hal tersebut untuk memecahkan masalah yang dihadapi dalam kehidupan sehari-hari. ${ }^{10}$

Terman memberi definisi inteligensi sebagai kemempuan untuk berpikir abstrak. ${ }^{11}$ Senada dengan terman, Bainbridge juga mendefinisikan inteligensi sebagai kemampuan mental umum untuk menerapkan pengetahuan dalam memanipulasi lingkungan, serta kemampuan untuk berpikir abstrak. ${ }^{12}$

Berdasarkan beberapa pendapat diatas, dapat disimpulkan bahwa inteligensi adalah kemampuan individu untuk berpikir absrak, sehingga mampu mecahkan masalah yang dihadapinya dalan kehidupan seharihari.

Menurut Baum, Viens, dan Slatin, kecerdasan linguistic adalah kemampuan untuk menggunakan bahasa, termasuk bahasa ibu dan bahasa-bahasa asing, untuk mengekspresikan apa yang ada dalam pikiran dan memahami orang lain (Yaumi \& Nurdin, 2013: 13). Mc Kenzie menambahkan bahwa kecerdasan linguistic disebut juga kecerdasan

10 Martini Jamaris, Orientasi Baru dalam Psikologi Pendidikan. (Bogor: Ghalia Indonesia, 2013). Hal. 91

${ }^{11}$ Sumadi Suryabrata, Psikologi Pendidikan. (Jakarta: PT. RajaGrafindo Persada, 2013). Hal. 125

${ }^{12}$ Muhammad Yaumi \& Nurdin Ibrahim, Pembelajaran Berbasis Kecerdasan Jamak (Multiple Intelligences) Mengidentifikasi dan Mengembangkan Multitalenta Anak. (Jakarta: Prenadamedia Group, 2013). Hal. 9 
verbal karena mencakup kemampuan untuk mengekspresikan diri secara lisan dan tertulis, serta kemampuan untuk meguasai bahasa asing. ${ }^{13}$

Munif Chatib mendefinisikan kecerdasan linguistik sebagai kemampuan menyusun pikiran dengan jelas dan mampu menggunakan kemampuan ini secara kompeten melalui kata-kata untuk mengungkapkan pikiran-pikiran dalam bicara, membaca, dan menulis, biasanya, kecerdasan ini dimiliki oleh para orator, negosiator, pengacara, atau para pemimpin negara di dunia. ${ }^{14}$

Berdasarkan beberapa pendapat di atas, dapat disipulkan bahwa inteligensi linguistic adalah kemampuan menggunakan bahasa yang diungkapkan melalui lisan atau tulisan.

\section{Ciri-ciri Inteligensi Linguistik}

Ciri-ciri yang melekat pada orang yang memiliki kecerdasan linguistic adalah sebagai berikut: ${ }^{15}$

1) Senang membaca semua bentuk bacaan.

2) Senang mencoret-coret dan menulis ketika mendengar atau berbicara.

3) Sering mengontak teman-teman melalui surat, email, atau mailing list.

4) Selalu memaparkan pandangan-pandangan cemerlang dihadapan orang lain.

5) Sering menulis jurnal (catatan pengalaman).

6) Senang teka-teki atau kata-kata silang

7) Mampu menulis lebih baik dari teman-teman seusianya (jika masih anak-anak).

8) Menyukai permainan dengan kata.

9) Suka pelajaran bahasa termasuk bahasa daerah dan bahasa asing.

${ }^{13}$ Muhammad Yaumi \& Nurdin Ibrahim, Pembelajaran Berbasis Kecerdasan Jamak (Multiple Intelligences) Mengidentifikasi dan Mengembangkan Multitalenta Anak. (Jakarta: Prenadamedia Group, 2013). Hal. 13.

${ }^{14}$ Besse Ratu, "Pengaruh Keserdasan Verbal Linguistik terhadap Hasil Belajar pada Mata Pelajaran Bahasa Indonesi Pesert Didik Kelas V MIN Batu Pitumpanua Kabupaten Wajo". 2017. Hal. 9.

${ }^{15}$ Muhammad Yaumi \& Nurdin Ibrahim, Pembelajaran Berbasis Kecerdasan Jamak (Multiple Intelligences) Mengidentifikasi dan Mengembangkan Multitalenta Anak. (Jakarta: Prenadamedia Group, 2013). Hal. 45-46. 
10) Senang bergabung pada acara-acara debat, dialog, atau berbicara dihadapan public.

Senada dengan pendapat di atas, Garrdner juga mengemukakan cara belajar orang yang memiliki kecerdasan linguistic memiliki indicator sebagai berikut:

1) Senang bermain dengan kata-kata

2) Senang membaca

3) Senang menulis

Kompetensi ideal yang ada yang ada di dalam linguistic diantaranya:

1) Bercerita

2) Permainan kosa kata

3) Berorasi

4) Mewawancarai

5) Berdebat

6) Berdiskusi

7) Membaca

8) Menulis (mengarang)

9) Mengedit

10) Mengingat

Sehingga dapat disimpulkan bahwa diantara ciri-ciri orang yang memiliki inteligensi linguistic yaitu senang bermain dengan kata-kata, senang mendengarkan kata-kata lisan,senang berbicara, berpidato, berdebat dan diskusi, senang membaca buku, senang menulis cerita, suka pelajaran bahasa termasuk bahasa daerah dan bahasa asing.

\section{Hasil Belajar}

Hasil belajar pada dasarnya terjadinya proses perubahan tingkah laku dari tidak tahu menjadi tahu, dari sikap yang kurang baik menjadi lebih baik, dari tidak terampil menjadi terampil pada peserta didik. ${ }^{16}$ Pada umumnya, hasil belajar dapat dikelompokkan menjadi tiga ranah, yaitu ranah kognitif, psikomotor, dan afektif. Secara eksplisit ketiga ranah ini tidak dapat dipisahkan satu sama lain. Setiap mata pelajaran selalu mengandung ketiga ranah tersebut, namun penekannya selalu berbeda. Mata pelajaran praktik lebih menekankan pada ranah psikomotor,

${ }^{16}$ Supardi, Penilaian Autentik Pembelajaran Afektif, Kognitif, dan Psikomotor (Konsep dan Aplikasi). (Jakarta: PT RajaGrafindo Persada, 2016). Hal. 2. 
sedagkan mata pelajaran pemahaman konsep lebih menekankan pada ranah kognitif. ${ }^{17}$

Menurut Nasution, keberhasilan belajar adalah suatu perubahan yang terjadi pada individu yang belajar, bukan saja perubahan mengenai pengetahuan, tetapi juga pengetahuan untuk membentuk kecakapan, kebiasaan, sikap, pengertian, penguasaan, dan penghargaan dalam diri individu yang belajar. ${ }^{18}$

Slameto Supardi mengemukakan prinsip-prinsip keberhasilan belajar yaitu: a) perubahan dalam belajar terjadi secara sadar, b) perubahan dalam belajar mempunyai tujuan, c) perubahan belajar secara positif, d) perubahan dalam belajar bersifat kontinu, e) perubahan dalam belajar bersifat permanen. ${ }^{19}$

Berdasarkan pemaparan di atas, dapat kita pahami bahwa hasil belajar adalah tahap pencapaian actual yang ditampilkan dalam bentuk perilaku yang meliputi aspek kognitif, afektif maupun psikomotor dan dapat dilihat dalam bentuk kebiasaan, sikap, dan penghargaan.

\section{Faktor-faktor yang Mempengaruhi Hasil Belajar}

Hasil belajara adalah kemampuan yang dimiliki siswa setelah ia menerima pengalaman belajarnya. Hasil belajar mempunyai peranan penting dalam proses pembelajaran. Proses penilaian terhdap hasil belajar dapat memberikan informasi kepada guru tentang kemajuan siswa dalam upaya mencapai tjuan-tujuan belajarnya melalui kegiatab belajar. Selanjutnya, dari informasi tersebut guru dapat menyusun dan membina kegiatan-kegiatan siswa lebih lanjut, baik untuk keseluruhan kelas maupun individu.

Faktor-faktor yang mempengaruhi hasil belajar menurut Munadi meliputi factor internal dan eksternal, yaitu: ${ }^{20}$

1) Faktor Internal

a) Faktor fisiologis

${ }^{17}$ Elis Ratnawulan \& A. Rusdiana, Evaluasi Pembelajaran. (Bandung: CV Pustaka Setia, 2015). Hal. 57.

18 Supardi, Penilaian Autentik Pembelajaran Afektif, Kognitif, dan Psikomotor (Konsep dan Aplikasi). (Jakarta: PT RajaGrafindo Persada, 2016). Hal. 2.

${ }^{19}$ Supardi, Penilaian Autentik Pembelajaran Afektif, Kognitif, dan Psikomotor (Konsep dan Aplikasi). (Jakarta: PT RajaGrafindo Persada, 2016). Hal. 2.

${ }^{20}$ Rusman, Belajar dan Pembelajaran Berorientasi Standar Proses Pendidikan. (Jakarta: Kencana, 2017). Hal. 130-131. 
Secara umum, kondisi fisiologis, seperti kondisi kesehatan yang prima, tidak dalam keadaan Lelah dan capek, tidak dalam keadaan cacat jasmani, dan sebagainya. Hal-hal tersebut dapat memengaruhi siswa dalam menerima materi pelajaran.

b) Faktor psikologis

Setiap individu dalam hal ini siswa pada dasarnya memiliki kondisi psikologi yang berbeda-beda, tentunya hal ini turut memengaruhi hasil belajarnya. Beberapa factor psikologis meliputi inteligensi (IQ), perhatian, minat, bakat, motif, motivasi, kognitif dan daya nalar siswa.

2) Faktor Eksternal

a) Faktor Lingkungan

Faktor lingkungan dapat memengaruhi hasil belajar. Factor lingkungan ini meliputi lingkungan fisik dan lingkungan sosial. Lingkungan alam mislanya suhu, dan kelembaban. Belajar pada tengah hari di ruang yang memiliki ventilasi udara yang kurang tentunya akan berbeda suasana belajarnya dengan yang belajar pagi hari yang udaranya masih segar dan di ruang yang cukup mendukung untuk bernafas lega.

b) Faktor Instrumental

Faktor instrumental adalah factor yang keberadaan dan penggunaannya dirancang sesuai dengan hasil belajar yang diharapkan. Factor-faktor ini diharapkan dapat berfungsi sebagai sarana untuk tercapainya tujuan-tujuan belajar yang telah direncanakan. Factor-faktor instrumental ini berupa kurikulum, sarana, dan guru.

\section{Tipe-tipe hasil belajar}

Mengacu pada pendapat Bloom terdapat tipe keberhasilan belajar dikaitkan dengan tujuan belajar meliputi kognitif, afektif, dan psikomotor.

1) Tipe keberhasilan belajar kognitif

Tipe keberhasilan belajar kognitif meliputi

a) Hasil belajar pengetahuan terlihat dari kemampuan mengetahui tentang hal-hal khusus, peristilahan, fakta-fakta khusus, prinsipprinsip, dan kaidah-kaidah.

b) Hasil belajar pemahaman terlihat dari kemampuan menerjemahkan, menafsirkan, menentukan, memperkirakan, dan mengartikan. 
c) Hasil belajar penerapan terlihat dari kemampuan memecahkan masalah, membuat bagan/grafik, menggunakan istilah atau konsep-konsep.

d) Hasil belajar analisis terlihat pada siswa dalam bentuk kemampuan mengenali kesalahan, membedakan, menganalisis unsur-unsur, hubungan-hubungan, dan prinsip-prinsip organisasi.

e) Hasil belajar sintesis terlihat pada diri siswa berupa kemampuan menghasilkan, menyusun kembali, merumuskan.

f) Hasil belajar evaluasi dapat dilihat pada diri siswa sejumlah kemampuan menilai berdasarkan norma tertentu, mempertimbangakan, memilih alternaitif.

2) Tipe Keberhasilan Belajar Psikomotor

Tipe keberhasilan belajar psikomotor meliputi:

a) Hasil belajar kesiapan terlihat dalam bentuk perbuatan.

b) Hasil belajar persepsi terlihat dari perbuatan.

c) Hasil belajar terbimbing akan terlihat dari kemampuan.

d) Hasil belajar Gerakan terbiasa terlihat dari penguasaan.

e) Hasil belajara Gerakan kompleks terlihat dari kemampuan siswa yaitu berketerampilan secara lancar, luwes, supel, gesit, dan lincah.

f) Hasil belajar penyesuaian pola Gerakan terlihat pada bentuk perbuatan yaitu mampu menyesuaikan diri dan bervariasi.

g) Hasil belajar kreativitas terlihat dari aktivitas-aktivitas yaitu mampu menciptakan yang baru dan berinisiatif.

3) Tipe Keberhasilan belajar afektif

Tipe keberhasilan bekajar afektif meliputi:

a) Hasil belajar penerimaan terlihat dari sikap dan perilaku yaitu mampu menunjukkan, mengakui, dan mendengarkan dengan sungguh-sungguh.

b) Hasil belajar dalam bentuk partisipasi akan terlihat dalan sikap dan perilaku yaitu mematuhi dan ikut serta aktif.

c) Hasil belajar penilaian/penentuan sikap terlihat dari sikap mampu menerima suatu nilai, menyukai, menyepakati, menghargai, bersikap positif atau negatif, serta mengakui. 
d) Hasil belajar mengorganisasikan terlihat dalam bentuk yaitu mampu membentuk system nilai, menangkap relasi antar nilai, bertanggungjawab dan menyatukan nilai.

e) Hasil belajar pembentuka pola hidup terlihat dalam bentuk sikap dan perilaku yaitu mampu menunjukkan, mempertimbangkan, dan melibatka diri. ${ }^{21}$

\section{Uji Normalitas}

Uji normalitas berguna untuk mengetahui setiap sampel yangakan digunakan berasal dari populasi yang terdistrubusi normal atau tidak. Uji normalitas data pada penelitian ini dilakukan dengan menggunakan program pengolahan data SPSS versi 16.0 melalui uji normalitas Kolmogorov-Smirnov dengan kriteria jika signifikansi $>0,05$ maka data berdistribusi normal, dan jika signifikansi $<0,05$ maka data tidak berdistribusi normal. Adapun hasilnya sebagai berikut:

One-Sample Kolmogorov-Smirnov Test

\begin{tabular}{|ll|r|}
\hline & & Unstandardized Residual \\
\hline $\mathrm{N}$ & 32 \\
Normal Parameters & Mean & .0000000 \\
& Std. Deviation & 18.36889351 \\
Most Extreme & Absolute & .171 \\
Differences & Positive & .103 \\
& Negative & -.171 \\
Kolmogorov-Smirnov Z & .969 \\
Asymp. Sig. (2-tailed) & .305 \\
\hline
\end{tabular}

Test distribution is Normal.

Berdasarkan hasil perhitungan uji One-Sample KolmogorovSmirnov Test diperoleh hasil signifikasi 0,305>0,05. Hal ini menunjukan bahwa data berdistribusi normal.

Pengaruh Inteligensi Linguistik terhadap Hasil Belajar Bahasa Arab Siswa Kelas XI MAN 1 Kota Cirebon

\section{Uji Hipotesis}

${ }^{21}$ Supardi, Penilaian Autentik Pembelajaran Afektif, Kognitif, dan Psikomotor (Konsep dan Aplikasi). (Jakarta: PT RajaGrafindo Persada, 2016). Hal. 2-4. 
Uji hipotesis digunakan untuk mengetahui ada tidaknya pengaruh antara variabel $x$ (kebiasaan belajar siswa) dan variabel y (prestasi bahasa Arab). Uji hipotesis yang digunakan dalam penelitian ini menggunakan uji regresi. Adapun hasilnya sebagai berikut.

Model Summary

\begin{tabular}{|l|r|r|r|r|}
\hline $\begin{array}{l}\text { Mode } \\
1\end{array}$ & $\mathrm{R}$ & R Square & $\begin{array}{c}\text { Adjusted R } \\
\text { Square }\end{array}$ & $\begin{array}{l}\text { Std. Error of } \\
\text { the Estimate }\end{array}$ \\
\hline 1 & $.074 \mathrm{a}$ & .005 & -.028 & 18.673 \\
\hline
\end{tabular}

a. Predictors: (Constant), Inteligensi Linguistik

Diketahui hasil perhitungan SPSS besarnya nilai korelasi (r) yaitu 0,074 dan nilai koefesien determinasi (r) square sebesar 0,05 yang meyatakan bahwa pengaruh variabel bebas (inteligensi linguistik) terhadap variabel terikat (hasil belajar bahasa Arab) adalah sebesar $0,5 \%$.

ANOVAb

\begin{tabular}{|ll|r|r|r|r|r|}
\hline \multicolumn{2}{|l|}{ Model } & \multicolumn{1}{c|}{$\begin{array}{c}\text { Sum of } \\
\text { Squares }\end{array}$} & Df & \multicolumn{1}{c|}{$\begin{array}{c}\text { Mean } \\
\text { Square }\end{array}$} & \multicolumn{1}{c|}{ F } & \multicolumn{1}{c|}{ Sig. } \\
\hline 1 & Regression & 57.565 & 1 & 57.565 & .165 & $.687 \mathrm{a}$ \\
Residual & 10459.904 & 30 & 348.663 & & \\
Total & 10517.469 & 31 & & & \\
\hline
\end{tabular}

a. Predictors: (Constant), Inteligensi Linguistik

b. Dependent Variable: Hasil Belajar

Diketahui hasil perhitungan SPSS dari tabel diatas diketahui bahwa nilai $\mathrm{F}$ hitung $=0,165$ dengan tingkat signifikansi sebesar 0,687>0,05 maka tabel regresi dapat dinyatakan tidak ada pengaruh yang signifikan antara variabel inteligensi linguistik dengan hasil belajar bahasa Arab.

Berdasarkan hasil uji regresi diatas, diperoleh hasil sig 0,687 $>0,05$ maka dapat disimpulkan bahwa H0 diterima dan Ha ditolak, hal tersebut menunjukan bahwa tidak terdapat pengaruh yang 
signifikan antara inteligensi linguistik tehadap hasil belajar Bahasa Arab siswa kelas XI MAN 1 Kota Cirebon.

\section{Kesimpulan}

Berdasarkan hasil dan pembahasan penelitian yang telah dilaksanakan di MAN 1 Kota Cirebon dapat diambil kesimpulan sebagai berikut: Pertama, hasil analisis data statistik deskriptif menunjukkan bahwa inteligensi linguistik siswa kelas XI MAN 1 Kota Cirebon dengan persentase 69\% tergolong tinggi; Kedua, hasil analisis data statistik deskriptif menunjukkan bahwa hasil belajar siswa kelas XI MAN 1 Kota Cirebon dengan mean 61,43 tergolong sedang; Ketiga, hasil penelitian menunjukkan bahwa tidak adanya pengaruh yang signifikan antara inteligensi linguistic dengan hasil belajar bahasa Arab siswa kelas XI MAN 1 Kota Cirebon.

Hal ini dibuktikan dengan data hasil penelitian yang dihitung menggunakan rumus uji regresi linier sederhana dengan menggunakan aplikasi SPSS 16.0 dimana hasil perhitungan signifikansi 0,687 > 0,05. Maka, Ho diterima dan Ha ditolak. Artinya tidak terdapat pengaruh yang signifikan antara inteligensi linguistik terhadap hasil belajar Bahasa Arab siswa kelas XI MAN 1 Kota Cirebon.

\section{Daftar Pustaka}

Arikunto, Suharsimi. 2006. Prosedur Penelitian Suatu Pendekatan Praktek. Jakarta: Rineka Cipta.

Danim, Sudarwan. 2011. Perkembangan Peserta Didik. Bandung: Alfabeta. Hayati, Tuti. 2013. Evaluasi Pembelajaran. Bandung: CV Insan Mandiri. Hermawan, Acep. 2011. Metode Pembelajaran Bahasa Arab. Bandung: PT. Remaja Rosdakarya.

Jamaris, Martini. 2013. Orientasi Baru dalam Psikologi Pendidikan. Bogor: Ghalia Indonesia.

Masrurah, Farhatin. "Kecerdasan Verbal-Linguistik Anak Melalui Pendekatan Beyond Centers and Circle Time (BCCT)". vol 6 no. 2, ( Desember 2014): 1-30.

Ratnawulan, Elis \& A. Rusdiana. 2015. Evaluasi Pembelajaran. Bandung: CV Pustaka Setia.

Ratu, Besse. "Pengaruh Keserdasan Verbal Linguistik terhadap Hasil Belajar pada Mata Pelajaran Bahasa Indonesi Pesert Didik Kelas V MIN Batu Pitumpanua Kabupaten Wajo". 2017. 
Rusman. 2017. Belajar dan Pembelajaran Berorientasi Standar Proses Pendidikan. Jakarta: Kencana.

Sugiyono. 2012. Metode Penelitian Kuantitatif, Kualitatif, dan RED. Bandung: Alfabeta.

Supardi, 2016. Penilaian Autentik Pembelajaran Afektif, Kognitif, dan Psikomotor (Konsep dan Aplikasi). Jakarta: PT RajaGrafindo Persada.

Suprijono, Agus. 2016. Cooperative Learning Teori dan aplikasi PAIKEM. Yogyakarta: Pustaka Pelajar.

Suryabrata, Sumadi. 2013. Psikologi Pendidikan. Jakarta: PT. RajaGrafindo Persada.

Uno, Hamzah B. \& Masri, Kuadrat. 2009. Mengelola Kecerdasan dalam Pembelajaran Sebuah Konsep Pembelajaran Berbasis Kecerdasan. Jakarta: PT. Bumi Aksara.

Warsono \& Hariyanti. 2016. Pembelajaran Aktif Teori dan Asesmen. Bandung: PT. Remaja Rosdakarya.

Yaumi, Muhammad \& Nurdin, Ibrahim. 2013. Pembelajaran Berbasis Kecerdasan Jamak (Multiple Intelligences) Mengidentifikasi dan Mengembangkan Multitalenta Anak. Jakarta: Prenadamedia Group. 